\title{
Impact of Mass Bathing and Religious Activities on Water Quality Index of Prominent Water Bodies: A Multilocation Study in Haryana, India
}

\author{
Anita Bhatnagar, ${ }^{1}$ Pooja Devi, ${ }^{1}$ and M. P. George ${ }^{1,2}$ \\ ${ }^{1}$ Department of Zoology, Kurukshetra University, Kurukshetra 136119, India \\ ${ }^{2}$ Delhi Pollution Control Committee, ISBT Building, Delhi, India \\ Correspondence should be addressed to Anita Bhatnagar; anitabhatnagar@gmail.com
}

Received 29 October 2015; Revised 27 January 2016; Accepted 11 February 2016

Academic Editor: L. M. Chu

Copyright (C) 2016 Anita Bhatnagar et al. This is an open access article distributed under the Creative Commons Attribution License, which permits unrestricted use, distribution, and reproduction in any medium, provided the original work is properly cited.

\begin{abstract}
The present study was designed to assess the impact of mass bathing and religious activities on water quality index (WQI) of prominent water bodies (eight) in Haryana, India. Water quality characteristics revealed significant increase in the values of nitrate, biochemical oxygen demand (BOD), turbidity, total dissolved solids (TDS), conductivity, total hardness, total alkalinity, and MPN count after the religious activities. The computed WQI at all the eight selected sites varied from 47.55 to 211.42 . The results revealed that there was a significant increase in the value of WQI after mass bathing or any other ritual performed. Out of eight water bodies studied three (sites 3, 4, and 5) were found under good water quality status; four sites $(1,2,6$, and 7$)$ depicted medium water quality but site 8 was found under poor water quality after the religious activities. The good water quality status of water bodies was correlated with larger size of the water bodies and less number of pilgrims; however, the poor WQI values may be attributed to smaller size of the water body and heavy load of pilgrims on such sites. Therefore, water of these religious water bodies needed to be regularly changed after mass bathing to protect the aquatic component from different contaminations.
\end{abstract}

\section{Introduction}

Surface water bodies have been the basic resource to fulfill all kinds of human requirements but unfortunately today water quality of these water resources is under severe environmental stress and under threat due to various types of anthropogenic activities and the condition is more pathetic in lentic water bodies. Among various types of anthropogenic actions religious activities like immersion of flour, oil, soap, ash, detergents, floral offerings, and mass bathing are also one of the important causes that affect the water quality of a water body. The holy water bodies of state of Haryana, India, have their immense value in terms of religious aspect, as people of Haryana, Punjab, and other states also are associated emotionally and spiritually with these water bodies. The religious activities are deeply rooted in its cultural heritage; millions of people take holy bath and perform religious activities and also do Aachman (drinking water) regularly on occasions like solar eclipse and new moon day irrespective of thinking about the water quality of the aquatic bodies. According to WHO [1] about $80 \%$ of all diseases in human beings are caused by water; therefore a regular monitoring of such water bodies is very essential for physicochemical and microbiological analysis to know the suitability of water under use not only to check the outbreak of diseases and occurrence of hazards but also to prevent the water from further deterioration.

For taking a better picture of water quality the data of various quality indicating parameters data could be aggregated into an overall index called water quality index (WQI). WQI can be defined as "a rating reflecting the composite influence of different water quality parameters on overall quality of water" [2,3]. WQI can be very important tool since it can be used for awareness of general public and policy makers to enhance the water quality. Therefore, the present study was conducted to depict the effect of religious activities 
TABLE 1: The selected water bodies, their location, and the religious activities performed.

\begin{tabular}{|c|c|c|c|}
\hline Site number & Name of water body & District & Activity \\
\hline$(1)$ & Kapalmochan tank & Yamunanagar & Full moon day (Kartik/Nov) on eve of Gurunanak birthday \\
\hline (2) & Kirmach pond & Kurukshetra & Kulotarn Tirth, fair at Sept month \\
\hline (3) & Ban Ganga Tirth tank & Kurukshetra & Vaishakhi (April) \\
\hline (4) & Brahmsarovar tank & Kurukshetra & Amavasya (new moon day), solar eclipse \\
\hline (5) & Jyotisar tank & Kurukshetra & Amavasya (new moon day), solar eclipse \\
\hline (6) & Saraswati Tirth tank & Pehowa, Kurukshetra & $\begin{array}{l}\text { Pind-dan and bathing during Sharadh (Sept-Oct), solar eclipse \& } \\
\text { Kartik amavasya }\end{array}$ \\
\hline (7) & Phalgu Tirth pond & Kaithal & Somvati amavasya of Sharadh \\
\hline$(8)$ & Pandu-Pindara Tirth pond & Jind & Somvari amavasya (new moon day on Monday), solar eclipse, Sharadh \\
\hline
\end{tabular}

TABLE 2: Relative weight (Wi) values of each parameter.

\begin{tabular}{|c|c|c|c|c|}
\hline S. number & Physicochemical parameters & $\begin{array}{l}\text { Water quality standards } \\
\text { for bathing or recreation }\end{array}$ & Assigned weight & Relative weight $W i=w i / \sum w i$ \\
\hline 1 & $\mathrm{pH}$ & $6.5-9.0[4], 6.5-8.5[5]$ & 4 & 0.1 \\
\hline 2 & Conductivity $(\Omega / \mathrm{cm})$ & $3000[6]$ & 4 & 0.1 \\
\hline 3 & $\operatorname{TDS}\left(\mathrm{mg} \mathrm{L}^{-1}\right)$ & $1500[6]$ & 4 & 0.12 \\
\hline 4 & Turbidity (NTU) & $5[7]$ & 2 & 0.05 \\
\hline 5 & $\mathrm{DO}\left(\mathrm{mg} \mathrm{L}^{-1}\right)$ & $\geq 5[5]$ & 4 & 0.1 \\
\hline 6 & $\mathrm{BOD}\left(\mathrm{mg} \mathrm{L}^{-1}\right)$ & $\leq 3[5]$ & 3 & 0.07 \\
\hline 7 & Total alkalinity $\left(\mathrm{mg} \mathrm{L}^{-1}\right)$ & $200[6]$ & 1 & 0.02 \\
\hline 8 & Total chloride $\left(\mathrm{mg} \mathrm{L}^{-1}\right)$ & $350[4]$ & 3 & 0.07 \\
\hline 9 & Total hardness $\left(\mathrm{mg} \mathrm{L}^{-1}\right)$ & $600[8,9]$ & 2 & 0.05 \\
\hline 10 & Total sulphate $\left(\mathrm{mg} \mathrm{L}^{-1}\right)$ & $350[4]$ & 4 & 0.1 \\
\hline 11 & Total nitrate $\left(\mathrm{mg} \mathrm{L}^{-1}\right)$ & $5.6[4]$ & 5 & 0.12 \\
\hline 12 & $\begin{array}{c}\text { Total coliform (MPN/100 mL } \\
\text { of water sample) }\end{array}$ & $\leq 500[6,10]$ & 4 & 0.1 \\
\hline
\end{tabular}

and mass bathing on water quality in terms of WQI of the eight prominent lentic water bodies of Haryana where such religious activities are carried out.

\section{Materials and Methods}

2.1. Study Area. A total of eight religious water bodies (lentic waters) in four districts of state of Haryana (Figure 1), India, were selected for the present study that were being used for the mass bathing and other religious activities (Table 1).

2.2. Sample Collection. Water samples for physicochemical analysis were collected two days before every religious activity and one day after religious activity from selected stations, in triplicate, in clean polythene bottles during February 2012 to March 2013 for physicochemical analysis. During the study period the religious activities were performed two times at stations Ban Ganga Tirth, Brahmsarovar, Jyotisar, Saraswati tank, and Pandu-Pindara Tirth; one time at stations Kapalmochan, Kulotaran Tirth, and Phalgu Tirth.

2.3. Physicochemical Analysis. Physicochemical parameters, namely, $\mathrm{pH}$, conductivity, total dissolved solids (TDS), turbidity, dissolved oxygen (DO), biochemical oxygen demand
(BOD), total alkalinity, chloride, hardness, total sulphate, and total nitrate, were determined using the standard procedures followed by APHA [11].

2.4. Microbiological Analysis. Concentration of total faecal coliform bacteria was reported as Most Probable Number per $100 \mathrm{~mL}$ (MPN/100 mL) following standard procedures APHA [11]. (i) Presumptive coliform test was done using multiple 5tubes MPN dilution technique using MacConkey Broth. (ii) Conformation test for total coliform was done by inoculating $1 \mathrm{~mL}$ inoculum from positive tube from presumption test in Brilliant green broth. (iii) For completed test, EMB (eosin methylene blue) agar plates were prepared and inoculated with positive tubes of confirmed test by streak plate method and incubated at $37^{\circ} \mathrm{C}$ for 24 to $48 \mathrm{~h}$ and observed for faecal coliform colonies.

2.5. Calculation of Water Quality Index (WQI). For computing the WQI three basic steps were followed [12]. All the parameters were assigned a weight according to their effect on the public health (Table 2).

Maximum weight of 5 was assigned to parameter like nitrate due to their major importance in water quality assessment [13]. $\mathrm{pH}$, conductivity, TDS, DO, and sulphate 
TABLE 3: Status of water quality based on WQI.

\begin{tabular}{lcc}
\hline S. number & WQI range & Status \\
\hline 1 & $<50$ & Excellent water quality \\
2 & $50-100$ & Good water quality \\
3 & $100-150$ & Medium or average water quality \\
4 & $150-200$ & Poor water quality \\
5 & $200-300$ & Very poor water quality \\
6 & $>300$ & Water unsuitable for drinking/bathing or any other human use \\
\hline
\end{tabular}

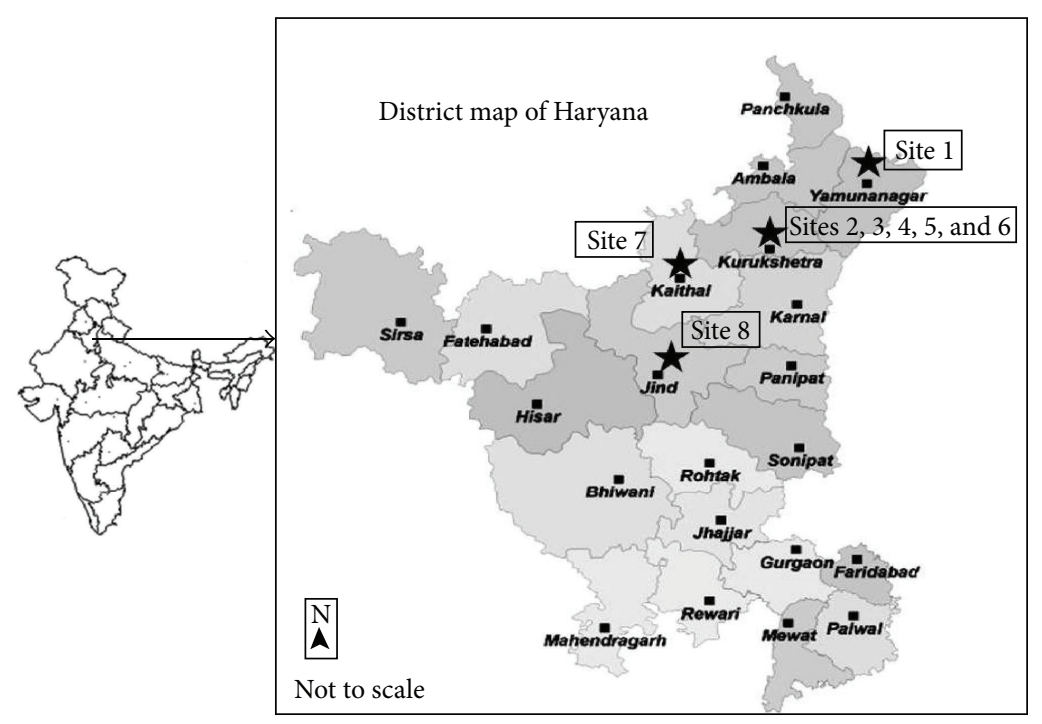

Site 1: Kapalmochan, Yamunanagar Site 2: Kulotaran Tirth, Kurukshetra Site 3: Ban-Ganga Tirth, Kurukshetra Site 4: Brahmsarovar, Kurukshetra Site 5: Jyotisar, Kurukshetra Site 6: Saraswati Tirth, Kurukshetra Site 7: Phalgu Tirth, Kaithal Site 8: Pandu-Pindara Tirth, Jind

FIGURE 1: Map showing different sites of Haryana selected under the study area.

were assigned the weight 4 according to Al-Mashagbah [14] and Srinivasamoorthy et al. [15]. MPN coliform was assigned weight 4 since it is the most important factor in India, where most of the serious diseases are waterborne [16]. Turbidity as well as total hardness was given the weight of 2 as it plays a fewer role in the water quality assessment [17]. In the second step, the relative weight $(W i)$ of each parameter was computed using

$$
W i=\frac{w i}{\sum_{i=1}^{n} w i},
$$

where $w i$ is the assigned weight of each parameter and $n$ is the number of parameters. Weight (wi) and relative weight $(W i)$ values and the standards for bathing water quality for each parameter were given in Table 2. In the third step, quality rating scale ( $q i)$ was calculated for each parameter using

$$
q i=\frac{c i}{s i} \times 100,
$$

where $q i$ is the quality rating, $c i$ is the observed concentration of each parameter in the water samples, and si represents the bathing standard value for each physicochemical parameter adopted from different recognized water quality organisations.

For the calculation of WQI, the SI (subindex) was computed for each given parameter as per the following equations:

$$
\mathrm{SI}=W i \times q i,
$$



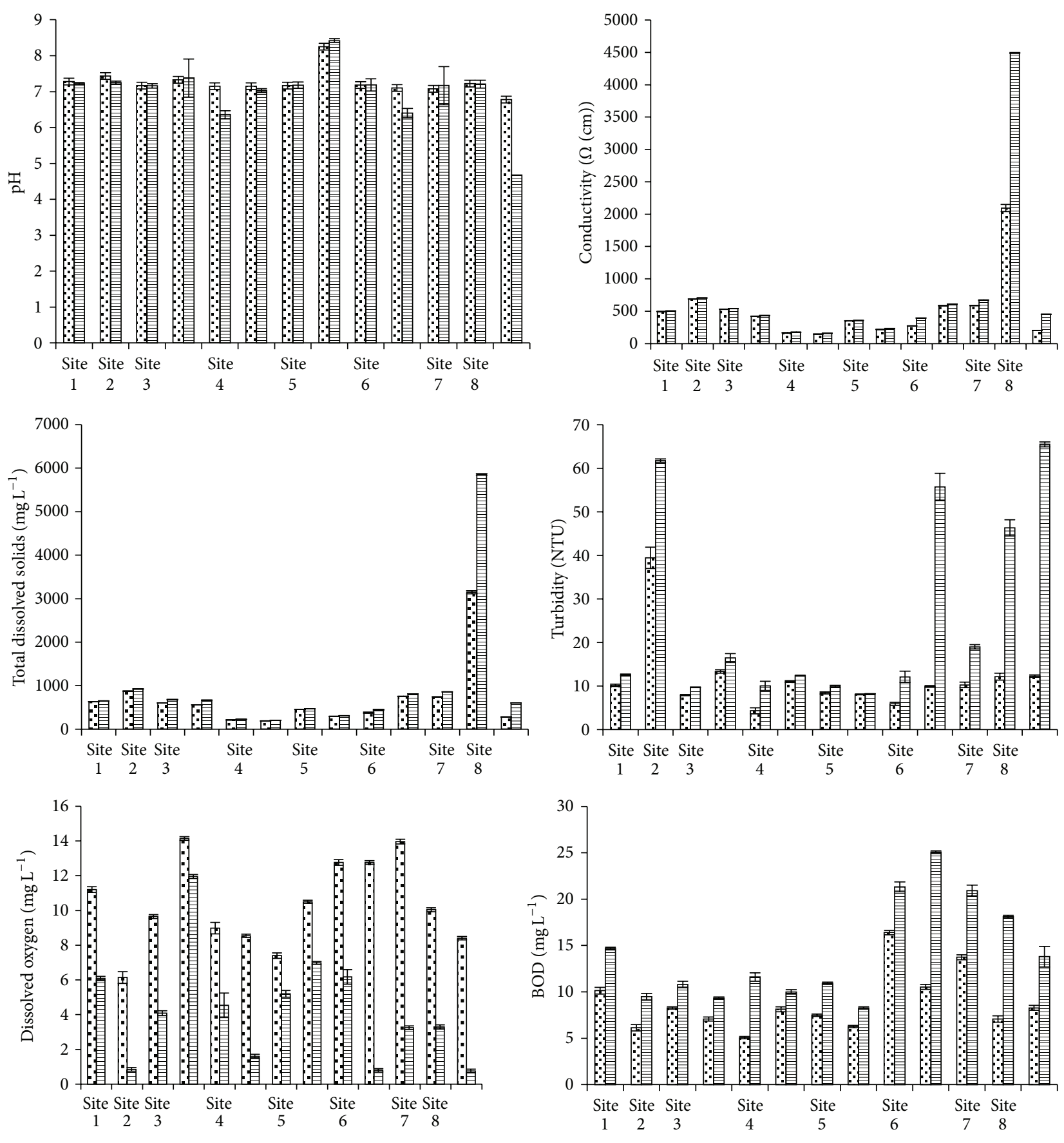

Before activity

目 After activity

FIGURE 2: Variations in $\mathrm{pH}$, conductivity, total dissolved solids, turbidity, dissolved oxygen, and biochemical oxygen demand (mean \pm standard error of the mean) before and after the religious activities at all the selected sites.

$$
\mathrm{WQI}=\sum_{i=1}^{n} \mathrm{SI} i
$$

where SI $i$ is the subindex of $i$ th parameters. WQI values were classified into six categories (Table 3), Ramakrishnaiah et al. [18] and Mishra and Borah [4].

\section{Results and Discussion}

Mean values of all the eleven physicochemical parameters (mean \pm SE) before and after the religious activities from February to March 2013 are represented in Figures 2 and 3. Significant $(P<0.05)$ increase in the values of conductivity, TDS, turbidity, BOD, total alkalinity, total chloride, total 

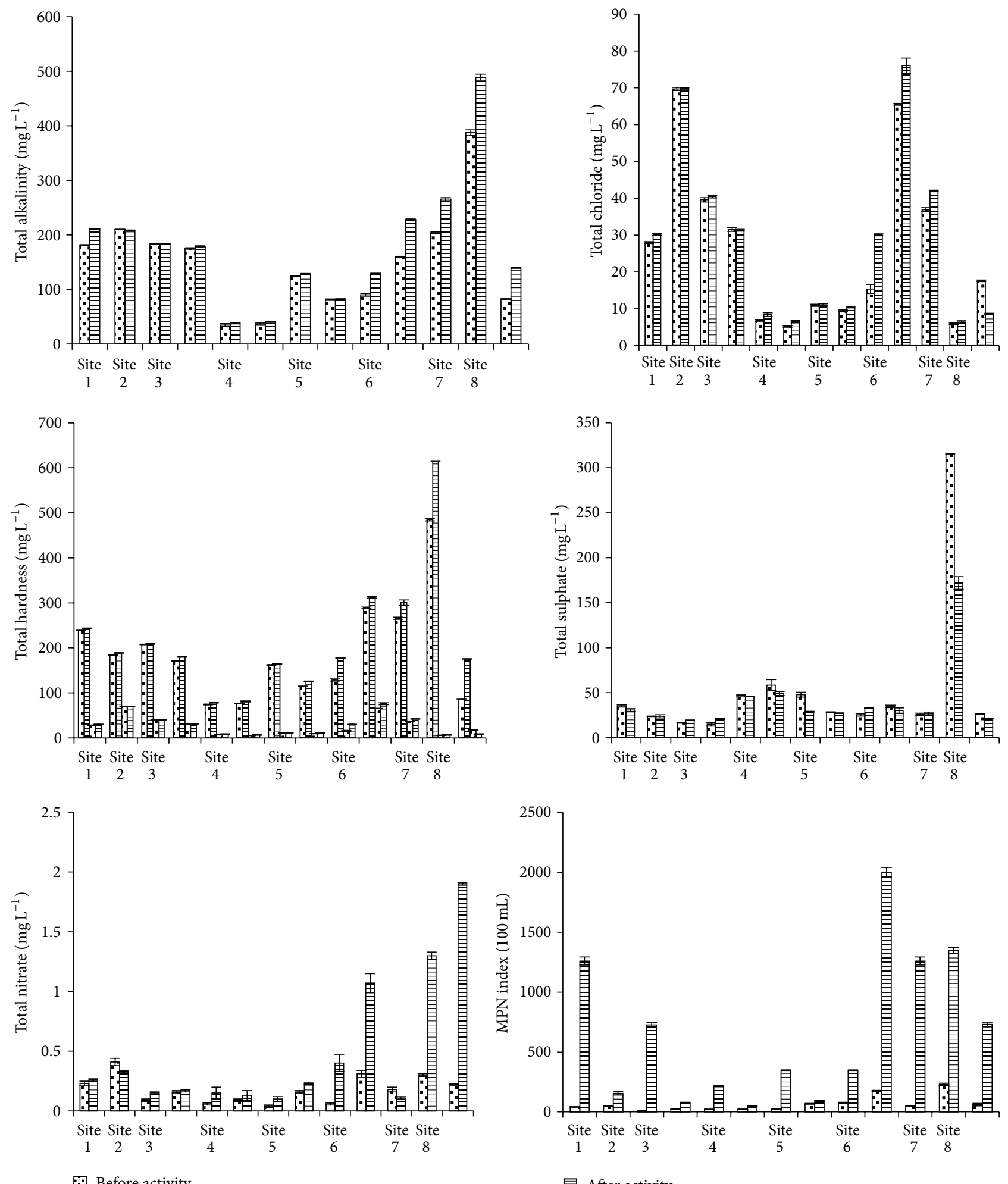

[.] Before activity

目 After activity

FIGURE 3: Variations in total alkalinity, total chloride, total hardness, total sulphate, and total nitrate (mean \pm standard error of the mean) before and after the religious activities at all the selected sites. 
hardness, and total nitrate and significant decrease in DO were observed at most of the sites after the mass bathing or other ritual activities. Similar observations were also reported by Vyas and Bajpai [19] and Sharma et al. [20]. The high organic matter and pollution load of pilgrims on the water bodies like bathing, adding ashes, flour, floral offerings, and urination may increase the chloride and nitrate contents of water in conformity with the findings of Kiran et al. [21], Gupta et al. [22]. Munawar [23] indicated that high concentration of chloride indicates high degree of organic pollution. Increase in the chloride may further be responsible for elevating the values of total dissolved solids and total hardness after the pilgrim's activities. Increase in the TDS further directly affects the conductivity as increase in the ion content will in turn increase the conductivity due to increase in the pollution load; similar observations were also recorded by [22]. Increase in total alkalinity may be attributed due to presence of basic salts of potassium and sodium along with those of calcium and magnesium as recorded by Jadhav et al. [24]. Overall minor differences were observed in $\mathrm{pH}$ before and after the religious activities. But the values of some parameters like conductivity, $\mathrm{pH}$, TDS, turbidity, DO, BOD, and total alkalinity were recorded above or below the permissible limit at some sites suggested by water quality guidelines for bathing given by various organizations (Table 2). Among all the sites the values of maximum water quality indicating parameters were recorded beyond the permissible limits of water quality standards of bathing waters at sites 6 and 8. Minor fluctuations in the values of chloride and sulphate were observed after the religious activities; however, all the values were recorded within the permissible limits (Table 2). Bacteria of coliform group are considered the primary indicators of faecal contamination by Raina et al. [25] that have been correlated with the incidence of gastrointestinal disorders (Morace and McKenzie [26]). The link between poor microbiological water quality and infectious diarrhea is well established [27-29]. An increase in MPN index of total coliform population was also recorded at all the site after mass bathing or any other religious activity which may be due to high level of pollution caused in the form of immersion of flour, floral offerings, bathing, urination, and so forth during these peak bathing dates. A probable reason behind this may be the addition of organic materials and faecal waste due to mass bathing of millions of pilgrims and the religious activities performed by them, supporting the earlier findings of Sood et al. [30].

On the basis of physicochemical and bacteriological variables before and after the religious activities, WQI was calculated for all the selected sites, which is shown in Table 4. On the basis of WQI values the sites 3, 4, and 5 were found to have good water quality status before and after the religious activities. The status of sites $1,2,6$, and 7 was recorded under the medium water quality after the religious activities. However, the water quality of site 8 was changed from good water quality to medium water quality after the Sharadh period and from medium water quality to very poor water quality after the solar eclipse period due to increase in the values of water quality index (Table 5 ). These results depicted that pollution load was maximum at sites 6 and 8 after the
TABLE 4: Water quality index values calculated at all the selected sites before and after the religious activities.

\begin{tabular}{lccc}
\hline \multicolumn{1}{c}{ Sites } & & Before activity & After activity \\
\hline Kapalmochan & Site 1 & 78.600 & 106.301 \\
Kulotarn Tirth & Site 2 & 91.306 & 113.064 \\
Ban Ganga & Site 3 & 67.187 & 79.101 \\
& & 77.622 & 84.115 \\
Brahmsarovar & Site 4 & 47.550 & 63.724 \\
& & 60.890 & 53.696 \\
Jyotisar & Site 5 & 58.934 & 70.686 \\
& & 60.773 & 59.941 \\
Saraswati Tirth & Site 6 & 87.625 & 101.256 \\
Phalgu Tirth & & 87.125 & 122.734 \\
Pandu-Pindara Tirth & Site 7 & 94.278 & 125.427 \\
& & 112.069 & 211.425 \\
& & 63.727 & 133.061 \\
\hline
\end{tabular}

religious activities and these were not found suitable for the bathing purpose or for the holy dip. This may be attributed to smaller size of these water bodies and heavy pilgrims load on these sites.

Pollution status was found to be lower at the sites 1,3 , 4 , and 5 indicating their good water quality status that was suitable for bathing purpose may be attributed due to larger sizes of the these water bodies and less number of bathers or pilgrims.

The higher values of water quality index at maximum sites after the religious activities were observed mainly due to increase in the values of physicochemical parameters, namely, nitrates, turbidity, BOD, TDS, total alkalinity, and total hardness, and also due to decrease in the values of DO.

\section{Conclusions}

The results of the present study clearly depict that there is an increase in the value of water quality index after the religious human activities due to increase in the values of nitrates, turbidity, BOD, TDS, total alkalinity, total hardness, and MPN and decrease in the values of DO. Out of eight water bodies studied three were found to be under good water quality status and four $(1,2,6$, and 7$)$ were designated under the medium water quality status whereas site 8 fell under the category of poor water quality after the religious activities. The sites with good WQI status (sites 3, 4, and 5) may be considered suitable for bathing purpose.

Regular change or mixing of water after mass bathing to protect the water body from different contaminations is recommended. Educational campaigns for awareness of the public regarding suitable use of water bodies without impairing the water quality are also required. To ensure that water quality standards are not violated, there is need of regular monitoring and surveillance of water quality in terms of physicochemical, biological, and bacteriological parameters taking suitable remedial measures to control pollution and prevent the depletion of the quality of lentic waters. 
TABLE 5: Water quality status of the selected sites on the basis of water quality index values before and after the religious activities.

\begin{tabular}{|c|c|c|c|}
\hline \multicolumn{2}{|c|}{ Sites } & \multirow{2}{*}{$\begin{array}{l}\text { Before activity } \\
\text { Good water quality }\end{array}$} & \multirow{2}{*}{$\begin{array}{l}\text { After activity } \\
\text { Medium water quality }\end{array}$} \\
\hline Kapalmochan & Site 1 & & \\
\hline Kulotarn Tirth & Site 2 & Good water quality & Medium water quality \\
\hline \multirow{2}{*}{ Ban Ganga } & \multirow{2}{*}{ Site 3} & Good water quality & Good water quality \\
\hline & & Good water quality & Good water quality \\
\hline \multirow{2}{*}{ Brahmsarovar } & \multirow{2}{*}{ Site 4} & Good water quality & Good water quality \\
\hline & & Good water quality & Good water quality \\
\hline \multirow{2}{*}{ Jyotisar } & \multirow{2}{*}{ Site 5} & Good water quality & Good water quality \\
\hline & & Good water quality & Good water quality \\
\hline \multirow{2}{*}{ Saraswati Tirth } & \multirow{2}{*}{ Site 6} & Good water quality & Medium water quality \\
\hline & & Good water quality & Medium water quality \\
\hline Phalgu Tirth & Site 7 & Good water quality & Medium water quality \\
\hline \multirow{2}{*}{ Pandu-Pindara Tirth } & \multirow{2}{*}{ Site 8} & Medium water quality & Very poor water quality \\
\hline & & Good water quality & Medium water quality \\
\hline
\end{tabular}

\section{Conflict of Interests}

The authors declare that there is no conflict of interests regarding the publication of this paper.

\section{References}

[1] WHO (World Health Organisation), Guidelines of Drinking Water Quality, vol. 1, WHO (World Health Organisation, Geneva, Switzerland, 2nd edition, 1993.

[2] R. A. Deininger and J. J. Macinans, A Water Quality of Environmental and Industrial Health, School of Public, University of Michigan, Ann Arbor, Mich, USA, 1971.

[3] R. D. Harkins, "An objective water quality index," Journal of Water Pollution Control Federation, vol. 46, no. 3, pp. 588-591, 1974.

[4] U. Mishra and P. Borah, "Assessment of indicator parameters to investigate the variations in groundwater quality of west districts of tripura using entropy and correlation," International Journal of Chemistry and Chemical Engineering, vol. 3, no. 3, pp. 215-222, 2013.

[5] Organization for Economic Co-operation and Development (OECD), Task Force for the Implementation of the Environmental Action Programme for Central and Eastern Europe, Caucasus and Central Asia: Regulatory Environmental Programme Implementation Network, ENV/EPOC/EAP/REPIN(2011)1/FINAL, Organization for Economic Co-operation and Development (OECD), Paris, France, 2011.

[6] Central Pollution Control Board (CPCB), Guidelines for Water Quality Management, Central Pollution Control Board (CPCB), Delhi, India, 2008.

[7] Queensland Government, Queensland Health Swimming and Spa Pool Water Quality and Operational Guidelines, Communicable Diseases Unit Public Health Services, 2004.

[8] UNESCO/WHO/UNEP, Water Quality Assessment-A Guide to the Use of Biota, Sediments and Water in Environmental Monitoring, 2nd edition, 2001.

[9] Bureau of Indian Standards (BIS), Indian Standard Drinking Water-Specifications, First Revison, Bureau of Indian Standards (BIS), 1991.

[10] V. K. Tyagi, A. Bhatia, R. Z. Gaur et al., "Impairment in water quality of Ganges River and consequential health risks on account of mass ritualistic bathing," Desalination and Water Treatment, vol. 51, no. 10-12, pp. 2121-2129, 2013.

[11] APHA, Standard Methods for the Examination of Water and Wastewater, APHA, AWWA, WPCF, Washington, DC, USA, 2005.

[12] M. Kumar, K. Kumari, A. L. Ramanathan, and R. Saxena, "A comparative evaluation of groundwater suitability for irrigation and drinking purposes in two intensively cultivated districts of Punjab, India," Environmental Geology, vol. 53, no. 3, pp. 553574, 2007.

[13] T. HemaLatha, G. N. Pradeep Kumar, P. Lakshminarayana, and A. Anil, "Assessment of groundwater quality index for upper Pincha Basin, Chittoor District, Andhra Pradesh, India using GIS," International Journal of Scientific and Engineering Research, vol. 3, no. 7, pp. 1-8, 2012.

[14] A. F. Al-Mashagbah, "Assessment of surface water quality of king abdullah canal, using physico-chemical characteristics and water quality index, Jordan," Journal of Water Resource and Protection, vol. 7, no. 4, pp. 339-352, 2015.

[15] K. Srinivasamoorthy, S. Chidambaram, M. V. Prasanna, M. Vasanthavihar, J. Peter, and P. Anandhan, "Identification of major sources controlling groundwater chemistry from a hard rock terrain-a case study from Mettur taluk, Salem district, Tamil Nadu, India," Journal of Earth System Science, vol. 117, no. 1, pp. 49-58, 2008.

[16] S. L. Dwivedi and V. Pathak, "A preliminary assignment of water quality index to Mandakini River, Chitrakoot," Indian Journal of Environmental Protection, vol. 27, no. 11, pp. 1036-1038, 2007.

[17] M. K. Rokbani, M. Guddari, and R. Bauhlila, "Use of Geographical Information System and Water Quality Index and assess ground water quality in EI Khairat Deep Aquifer (Enfidha, Tunisian Sahel)," Iranica Journal of Energy and Environment, vol. 2, no. 2, pp. 133-144, 2011.

[18] C. R. Ramakrishnaiah, C. Sadashivaiah, and G. Ranganna, "Assessment of water quality index for the groundwater in Tumkur Taluk, Karnataka State, India," E-Journal of Chemistry, vol. 6, no. 2, pp. 523-530, 2009.

[19] A. Vyas and A. Bajpai, "Water quality survey and monitoring of idol immersion in context of Lower lake," in Proceedings of Taal 2007: The 12th World Lake Conference, pp. 1818-1821, Bhopal, India, 2008. 
[20] V. Sharma, S. Bhadula, and B. D. Joshi, "Impact of mass bathing on water quality of Ganga River during Maha Kumbh-2010," Journal of Nature and Science, vol. 10, no. 6, pp. 1-5, 2012.

[21] B. R. Kiran, K. Harish, M. Ravikumar, E. T. Puttaiah, and C. D. Kamat, "Water quality assessment of Bhadrariver with special reference to industrial pollution," Indian Journal of Environmental protection, vol. 26, no. 2, pp. 148-152, 2006.

[22] A. K. Gupta, K. Mishra, P. Kumar, C. Singh, and S. Srivastava, "Impact of religious activities on the water characteristics of prominent ponds at Varanasi (U.P.), India," Plant Archives, vol. 11, no. 1, pp. 297-300, 2011.

[23] M. Munawar, "Limnological studies on freshwater ponds of hyderabad-India," Hydrobiologia, vol. 36, no. 1, pp. 105-128, 1970.

[24] S. B. Jadhav, N. S. Chavan, and M. V. Gokhale, "Effect of ritual activity on the lentic water resources of Jotiba (Wadi-Ratnagiri), Kolhapur district, Maharashtra," Ecology, Environment and Conservation, vol. 15, no. 1, pp. 71-75, 2009.

[25] P. S. Raina, F. L. Pollari, G. F. Teare, M. J. Goss, D. A. J. Barry, and J. B. Wilson, "The relationship between E. coli indicator bacteria in well-water and gastrointestinal illnesses in rural families," Canadian Journal of Public Health, vol. 90, no. 3, pp. 172-175, 1999.

[26] J. L. Morace and S. W. McKenzie, "Faecal-indicator bacteria in the Yakima River Basin, Washington - an examination of 1999 and 2000 synoptic-sampling data and their relation to historical data," Water-Resources Investigations Report 02-4054, 2002.

[27] A. A. Cronin, D. Shrestha, N. Cornier, F. Abdalla, N. Ezard, and C. Aramburu, "A review of water and sanitation provision in refugee camps in association with selected health and nutrition indicators-the need for integrated service provision," Journal of Water and Health, vol. 6, no. 1, pp. 1-13, 2008.

[28] T. T. Do, T. T. Bui, K. Molbak, D. C. Phung, and A. Dalsgaard, "Epidemiology and aetiology of diarrhoeal diseases in adults engaged in wastewater-fed agriculture and aqua-culture in Hanoi, Vietnam," Tropical Medicine and International Health, vol. 12, no. 2, pp. 23-33, 2007.

[29] W. E. Oswald, A. G. Lescano, C. Bern, M. M. Calderon, L. Cabrera, and R. H. Gilman, "Fecal contamination of drinking water within peri-urban households, Lima, Peru," American Journal of Tropical Medicine and Hygiene, vol. 77, no. 4, pp. 699704, 2007.

[30] A. Sood, K. D. Singh, P. Pandey, and S. Sharma, "Assessment of bacterial indicators and physicochemical parameters to investigate pollution status of Gangetic river system of Uttarakhand (India)," Ecological Indicators, vol. 8, no. 5, pp. 709-717, 2008. 

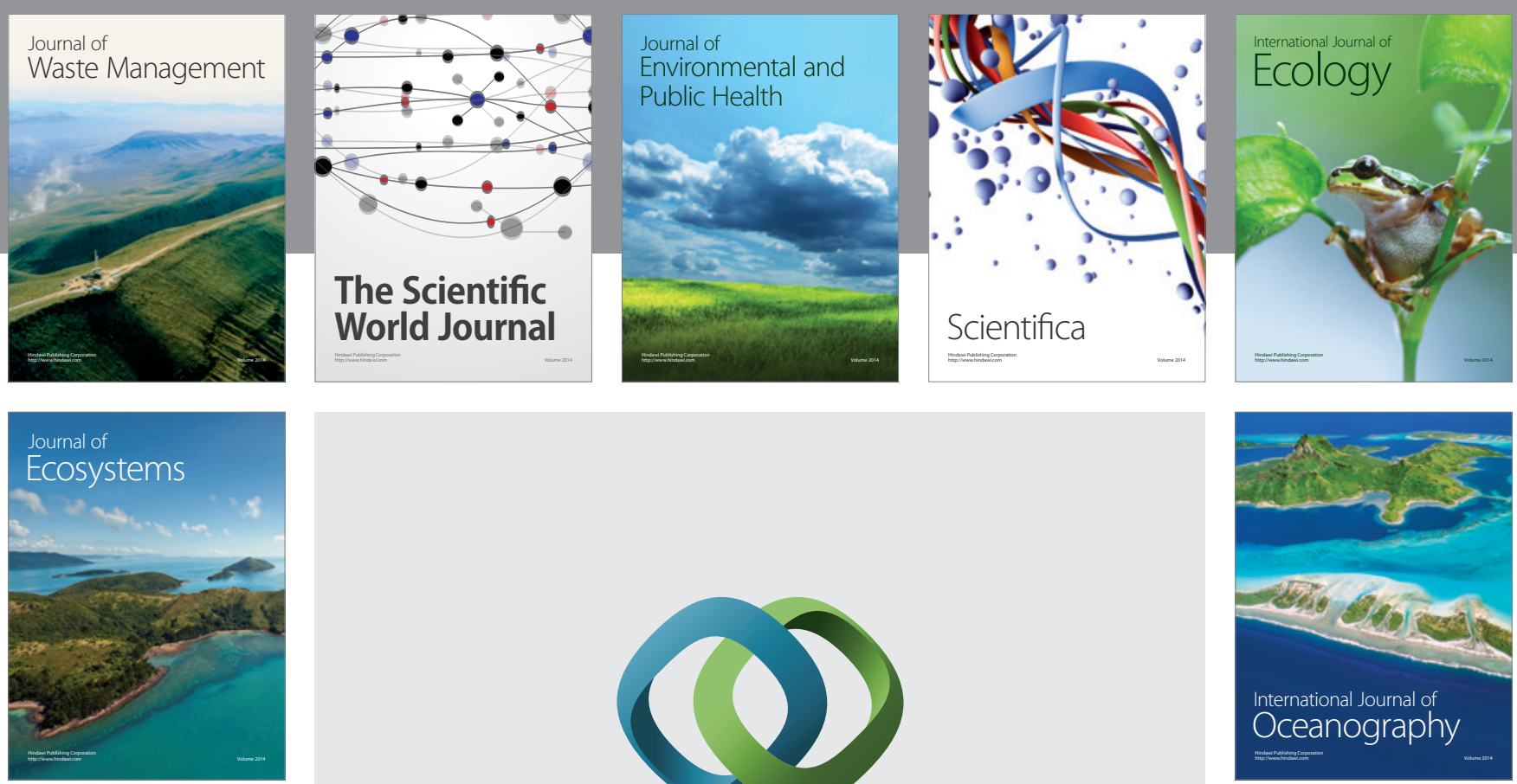

The Scientific World Journal
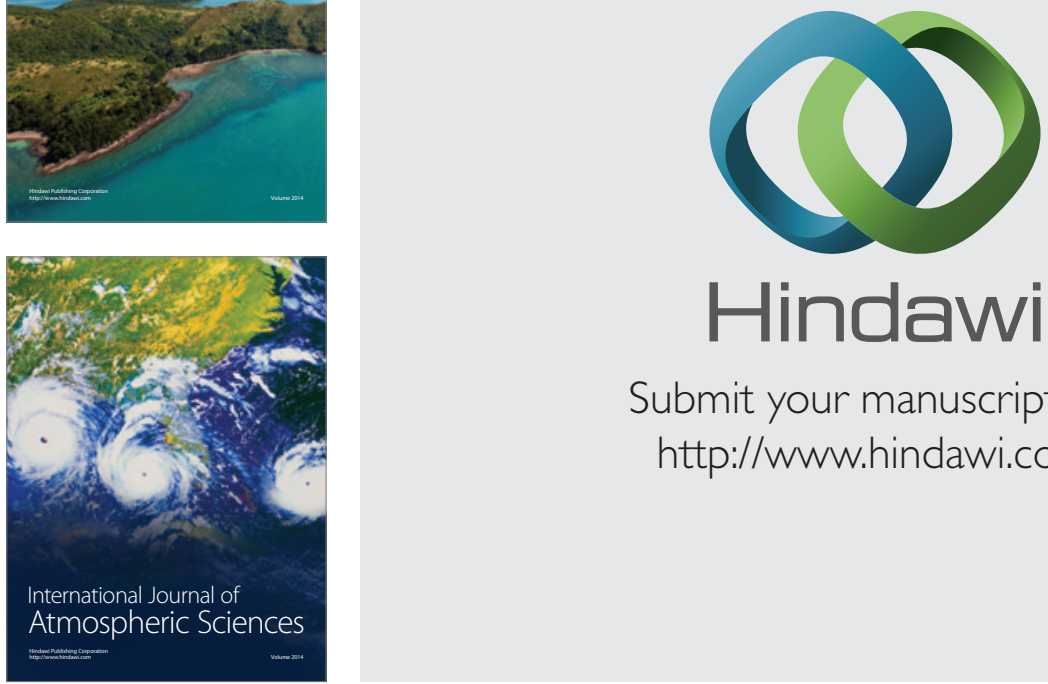

\section{Hindawi}

Submit your manuscripts at

http://www.hindawi.com
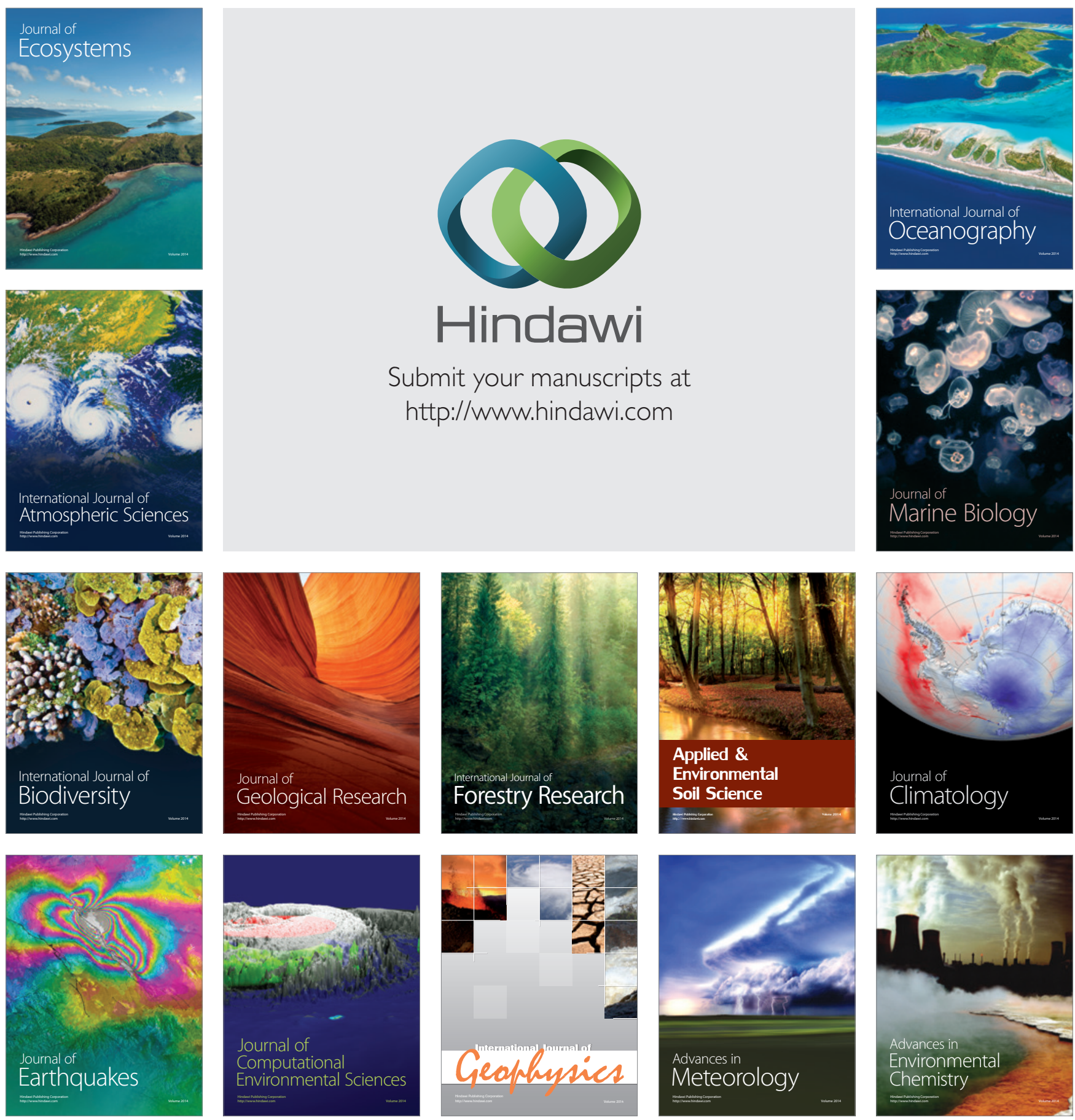